УДК 338.24:640.41

DOI: https://doi.org/10.37320/2415-3583/16.10

Капліна Т.В.

доктор технічних наук, професор

Полтавський університет економіки і торгівлі ORCID: https://orcid.org/0000-0002-9445-5684

Красномовець В.A.

кандидат економічних наук, доцент Черкаський національний університет імені Богдана Хмельницького ORCID: https://orcid.org/0000-0001-5806-8348

\title{
ІННОВАЦІЇ В СИСТЕМІ РОЗВИТКУ ПІДПРИЕМСТВ ГОТЕЛЬНОГО ГОСПОДАРСТВА
}

Однією з найважливіших запорук успішного розвитку підприємств готельної галузі є впровадження у практику діяльності інновацій. Конкурентну перевагу в нинішніх умовах здобудуть ті підприємства, щчо зуміють першими та якнайкраще підлаштуватися до нових реалій та правил гри. У статті обтрунтовано необхідність упровадження інновацій у практику діяльності підприємств готельної галузі. Визначено їх суть та наведено основні функиії. 3-поміж багатьох видів у статті розглянуто одні з найпоширеніших: інфраструктурні та технологічні інновачії. Інфраструктурні інноваиії передбачають відхід від традиційного формату будівлі або місия розташування закладу. Сфера прояву технологічних інновачій надзвичайно широка і включає в себе як застосування нових інформаційних систем у маркетинговій політиці, так і впровадження нових технологічних засобів, щзо покликані зробити максимально комфортним перебування та привернути увагу гостя. У статті особливу увагу присвячено аналізу екологічних інновацій, який розглядаємо як підвид у складі технологічних. Визначено суть та сфери впровадження екологічних інновацій у практику функціонування підприємств готельної галузі.

Ключові слова: інновачії, розвиток, підприємства готельного господарства, екологічні інновачії, «зелена» економіка.

Постановка проблеми. Світова пандемія 2019-2021 рр. внесла значні корективи в темпи та показники розвитку як усієї туристичної галузі, так i готельно-ресторанного сектору. Конкурентну перевагу в нинішніх умовах здобудуть ті підприємства, що зуміють першими та якнайкраще підлаштуватися до нових реалій та правил гри. Особливо важливо створювати конкурентні переваги, що можливо досягти шляхом упровадження інноваційних технологій. Розвиток готельного сектору не стоїть на місці. Щорічно з'являються все більш інноваційні технології, які дають змогу зробити перебування гостя в готелі максимально комфортним і цікавим. Уже зараз багато готелів істотно відрізняються від інших. Відсутність стійки реєстрації, використання останніх технічних нововведень, унікальні послуги або повна відсутність «видимого персоналу» - ці та багато інших нововведень дають змогу привернути увагу сучасного гостя.

Аналіз останніх досліджень і публікацій. Окремим питанням інноваційного розвитку світового готельного господарства присвячено праці Н.М. Влащенко, Н.М. Гоблик-Маркович, С.М. Журавльова, Т.В. Лисюк, О.С. Камушкова, О.В. Печериці та ін. Технологічні нововведення в готельній галузі є предметом аналізу В.С. Ковешнікова. Питання інноваційного управління розвитком підприємств готельно-ресторанного господарства порушує у своїх працях О.Ю. Давидова.

Мета статті полягає у комплексному аналізі та узагальненні досвіду застосування окремих інноваційних підходів у розвитку підприємств готельної галузі.

Виклад основного матеріалу. Нині вся галузь туризму функціонує в умовах глобальних соціальноекономічних змін, тому впровадження нових техно- логій $є$ вимушеним та абсолютно необхідним кроком. Поняття «інновація» міцно та впевнено увійшло в наше життя в усіх його сферах у формі нових інформаційних, технологічних, телекомунікаційних, управлінських та інших форм нововведень. Зазвичай під інноваціями розуміють нове, досі не використовуване явище в практиці функціонування окремого підприємства або в галузі чи сфері загалом.

Інновації виконують низку функцій [11, с. 37]. По-перше, за допомогою інновацій залучаються нові продуктивні сили, які сприяють зростанню продуктивності праці, призводять до підвищення ефективності виробництва; з їх допомогою відбувається скорочення різних витрат.

По-друге, інновації відіграють важливу роль у підвищенні рівня життя людей. Це досягається за рахунок того, що за допомогою застосування інноваційних технологій виробляється різноманітна кількість продуктів і послуг, які задовольняють потреби кожної людини.

По-трете, інновації виконують таку функцію, як підтримання рівноваги на ринку між попитом і пропозицією.

По-четверте, завдяки інноваціям відбувається розвиток творчого потенціалу людського інтелекту, вони стимулюють його і стають результатом творчості [11, с. 37].

Аналіз наукових праць, присвячених дослідженню питань упровадження інновацій у готельному господарстві, дав змогу виокремити кілька основних їх сфер застосування та прояву. Наведені приклади з практики функціонування як вітчизняних, так і зарубіжних готелів дають змогу краще зрозуміти їхню специфіку.

Яскравим прикладом інфраструктурних інновацій можна назвати нестандартні та подекуди навіть дива- 
куваті для типового готелю варіанти виконання. Одним iз найвідоміших готелів, що був створений під знаком «дивацтва», вважають Dog Bark Park Inn у місті Коттонвуд (США, Айдахо), у 5 км від Тhe Monastery of St. Gertrude \& Historical Museum. Будинок побудовано у формі собаки породи бігль, готель має два поверхи [5]. Єдність природи й людини показує готель The Giraffe Manor, який за виглядом характерний для англійської архітектурі; він розташований у передмісті кенійської столиці Найробі на території притулку для жирафів. Готель The Giraffe Manor пропонує насолодитися своїм гостям захоплюючою процедурою годування й фотографування жирафа під час сніданку за власним столом [4]. Один із найбільш незвичайних і унікальних готелів у світі, який розташований у Дубаї, отримав назву Hydropolis Undersea Resort. Його головною особливістю стало те, що знаходиться він біля узбережжя Перської затоки на глибині близько 18 м. Площа готелю становить 260 га, а на його будівництво пішло 490 млн доларів. Нині готель має 10 зірок, що робить його не тільки вельми незвичайним, а й максимально комфортним і розкішним. Апартаменти в Hydropolis Undersea Resort обійдуться вам в 5,5 тис доларів за одну лише добу. Усього в готелі розташовано 220 елітних номерів, які зроблено у вигляді повітряних бульбашок. Доставка відвідувачів проводиться за допомогою спеціального потяга, що рухається по довгому тунелю від самого берега і до фойє готелю [12].

Подібних прикладів незвичного розташування i виконання приміщень засобів розміщення у світі $\epsilon$ чимало. Саме ця нестандартність та диковинність $є$ інноваційним кроком, що приваблює туристів.

Утім, одним із найпопулярніших напрямів упровадження інновацій у готельних підприємствах $\epsilon$ технологічний складник. Сфера його прояву надзвичайно широка і включає у себе як застосування нових інформаційних систем у маркетинговій політиці, так і впровадження нових технологічних засобів, що покликані зробити максимально комфортним перебування та привернути увагу гостя.

Наприклад, компанія Starwood Hotels and Resorts упровадила в практику готелів нову технологію, що дає змогу гостям відкривати і закривати двері в номер дотиками до екрану телефону. Ця технологія є частиною нової програми впровадження високих технологій у готельний бізнес [6, с. 42]. Аналогічні технології $є$ й у мережі Hilton. Компанія активно впроваджує нові сервіси, такі як цифрова система реєстрації і вибір номеру завдяки доступному електронному плану готелю, що реалізовуються більше ніж у 4 тис готелів Hilton [6, c. 42].

Набувають також популярності консьєрж-боти. Віртуальний консьєрж розповість про послуги готелю, допоможе замовити обслуговування в номер, дасть рекомендації щодо вибору барів та ресторанів і зможе прийняти від клієнта скаргу. За необхідності за допомогою гаджета можна викликати реальний персонал готелю [2].

Окремим важливим складником технологічних інновацій у готельній сфері вважаємо екологічні інновації. Аналіз профільної літератури, присвяченої дослідженню даного питання, засвідчив, що даний аспект $\epsilon$ абсолютно не дослідженим у діяльності готельних підприємств. Водночас ООН та іiі структурні підрозділи актуалізують основний принцип «зеленої» економіки - «економічно вигідно те, що екологічно безпечно». Так, згідно з висновками експертів UNWTO i UNEP, викладеними в доповіді «Туризм і «зелена» економіка», сценарій розвитку територій за програмою «зелених» інвестицій» дасть змогу до 2050 р. скоротити енергоспоживання в туристській сфері на 44\%, а емісії CO2 - на 52\% [3]. Досягти такого ефекту можливо, використовуючи комбінацію заходів, серед яких упровадження технологічних інновацій, перехід до екологічно чистого транспорту і використання в готельній сфері ефективного енергетичного та екологічного менеджменту [3]. Важливу роль при цьому відіграватимуть і зміни в поведінці туристів. І вони вже сталися. Так, згідно з дослідженнями Корнелльського університету, близько 90\% опитаних постояльців готелів готові переплатити за додаткові екологічні продукти і послуги [10, с. 38]. Значна кількість гостей готелів, особливо ті, у яких дохід вище середнього, стурбовані проблемами охорони навколишнього середовища. Вони усвідомлюють, що їхні власні дії і робота готелів, послугами яких вони користуються, чинять негативний вплив на природу. Подібного роду свідомість дає «зеленим» готелям хороші шанси для подальшого розвитку.

На підставі концептуальних подібностей у визначеннях поняття «екологічна інновація», а також 3 огляду на відмінності, які існують у вітчизняних та закордонних учених, поділяємо думку О.В. Печериці про те, що екологічні інновації - це нові продукти, технології, а також способи організації виробництва і соціальні програми, що складаються 3 нових або змінених процесів, методів, систем, під час використання яких у різних сферах діяльності відбувається поліпшення стану навколишнього середовища, зниження екологічних ризиків, забруднень або інших негативних екологічних наслідків [9, с. 49].

Уже сьогодні власники багатьох готелів, що зрозуміли необхідність в аспекті впливу на навколишнє середовище та бачать пріоритетним для себе функціонування в даному сегменті, проводять різноманітні заходи починаючи від будівництва 3 використанням екологічно чистих матеріалів і закінчуючи установкою автономних систем для отримання електроенергії та сортування сміття. Загалом фахівці [7-9], окрім власне створення самого закладу з урахуванням екологічних норм, виділяють такі основні сфери готельного бізнесу, в яких можливе впровадження екоінновацій: утилізація відходів, прибирання номерного фонду, навчання персоналу, послуги організації харчування, інтер'єр готелю, закупівля екологічної сировини і матеріалів та зручності в готелі. Поділяємо думку О.В. Печериці, що завдяки впровадженню екологічних інновацій у цих сферах готель може помітно знизити негативний вплив на здоров'я людини і навколишнє середовище.

Із кожним роком туристів, які вибирають екологічний і безпечний для природного середовища відпочинок, стає все більше. Турбота про безпеку людей і охорона навколишнього середовища $є$ невід'ємною частиною сучасної туристичної індустрії. Представники туристичної та готельної індустрій відзначають, що мандрівники стали відповідальнішими у цьому 
питанні. Згідно з дослідженням туристичної асоціацiї Association of British Travel Agents (ABTA), кожен третій відпочиваючий уважає, що, крім традиційного (кількість зірок), готелі повинні мати й екологічний рейтинг. Порівняно з 2010 р. у 2011 р. частка відповідальних туристів, які вибирають екологічний відпочинок, зросла з 29\% до 33\% [3]. Дотримуватися екологічних норм під час подорожей готові $38 \%$ опитаних жінок і 49\% туристів-«космополітів», що здійснюють відпочинок кілька разів на рік [10, с. 39]. Дослідження АВТА підтверджують, що компанії, які поліпшують свій сервіс із погляду безпеки та охорони навколишнього середовища, мають перевагу перед конкурентами. Споживачі відзначають, що готові більше заплатити за відпочинок, який відповідає екологічним нормам і стандартам [9, с. 50].

Рівень екологічності готелю визначають спеціальні сертифіковані агенції чи організації. Однією 3 найпопулярніших програм екосертифікації $\epsilon$ програма добровільної міжнародної екологічної сертифікації установ готельного бізнесу Green key. Вона спрямована на зменшення впливу на навколишнє середовище, сприяння реалізації сталого управління готельним бізнесом, а також на підвищення екологічної інформованості.

Green key («Зелений ключ») - міжнародний знак якості, що присуджується готелям за досягнення у сфері захисту навколишнього середовища. Щоб отримати екосертифікат, готель має відповідати п'ятдесяти обов'язковим критеріям. Критерії охоплюють 13 напрямів: екологічний менеджмент, інформація для гостей, водоспоживання, енергозабезпечення, прибирання i прання, управління відходами, залучення персоналу, страви та напої, адміністрування, внутрішнє середовище, «зелені» зони, природоохоронна діяльність та корпоративна соціальна відповідальність [1].
Водночас, екологічна інноваційна діяльність у сфері гостинності, крім охорони навколишнього середовища, повинна бути спрямована на освоєння нових реалізованих послуг, підвищення якості послуг, автоматизацію надання послуг і зниження витрат.

Слід зазначити, що на шляху до впровадження екологічних інновацій у готельний бізнес існують, звичайно, і перешкоди. Зазвичай до них відносять високу вартість упровадження екологічних інновацій або їх розроблення, кількість ресурсів (тимчасових і інтелектуальних), які необхідно витратити на те, щоб навчитися працювати з цими інноваційними технологіями. Вочевидь, найголовніша перешкода полягає у тому, що керуючий персонал передусім цікавиться отриманням доходів із робочого підприємства і нічого змінювати не хоче. Довести власнику готелю, що впровадження екологічних інновацій у перспективі дасть можливість отримати значно більший дохід - завдання не 3 простих. Однак правила конкуренції посилюються, і сьогодні той, хто не зробив ставку на екологічні інновації, ризикує дуже серйозно програти в майбутньому $[13$, c. 125$]$.

Висновки. Таким чином, підсумовуючи вищесказане, відзначимо, що інновації в готельному бізнесі розвиваються дуже швидко. Причиною цього служить $\epsilon$ закономірне бажання готельєрів залучити максимальну кількість гостей, продавши при цьому найбільшу кількість послуг, і здобути лояльність мандрівника до себе, до свого бренду, свого готелю, а в ідеалі - зробити його постійним споживачем. Значною мірою у створенні оригінального готельного продукту допомагає реалізація інфраструктурних та впровадження такого різновиду технологічних інновацій, як екологічні.

Предметом подальших авторських розвідок $є$ аналіз інших видів (управлінських, соціальних) інновацій у діяльності готельних підприємств.

\section{Список використаних джерел:}

1. Official web site of programme Green Key. URL: http://www.greenkey.global/green-key-sites (дата звернення: 29.01.2021).

2. Pijak Jana. 25 High Tech Hotel Innovations. URL: https://www.trendhunter.com/slideshow/hotel-innovations/ (дата звернення: 29.01.2021).

3. Tourism investing in energy and resource efficiency. United Nations Environment Programme. URL: http://biodiv.unwto.org/en (дата звернення: 29.01.2021).

4. Бутік-готель Giraffe Manor: сніданок із жирафами. URL: http://www.travel.ru/wow/giraffe_manor.html (дата звернення: 05.01.2021).

5. Готель всередині собаки Dog Bark Park Inn, Коттонвуд (штат Айдахо), США. URL: http://www. mirkrasiv.ru/articles/ gostinica-vnutri-sobaki-dog-bark- park-inn-kotonvud-shtat-aidaho-ssha.html (дата звернення: 05.01.2021).

6. Грибанова Д.А. Использование инноваций в деятельности гостиничных предприятий. Современные инновации. 2018. № 3(31). С. 41-43.

7. Духовная Л.Л., Холодцова И.И. Инновационные технологии в гостиничном бизнесе. Сервис в России и за рубежсом. 2014. № 7. С. 58-73.

8. Камушков О.С., Ткач В.О., Язіна В.А. Інновації світового готельного господарства. Причорноморські економічні студії. 2019. Вип. 48(2). С. 52-55. URL: http://nbuv.gov.ua/UJRN/bses_2019_48(2)_11 (дата звернення: 18.10.2020).

9. Печерица Е.В. Зарубежный опыт применения экологических инноваций в средствах размещения. Национальные интересы: приоритеты и безопасность. 2013. № 34(223). С. 49-60.

10. Печерица Е.В. Российский опыт применения экологических инноваций в средствах размещения (на примере СевероЗападного федерального округа). Начиональные интересы: приоритеты и безопасность. 2013. № 42(231). С. 38-45.

11. Печерица Е.В. Теоретические и практические аспекты внедрения инноваций в туризме и гостиничном бизнесе. Физическая культура. Спорт. Туризм. Двигательная рекреачия. 2016. Т. 1. № 2. С. 34-41.

12. Роскошь во всем: подводный отель в Дубаи. URL: https://planetofhotels.com/guide/ru/blog/roskosh-vo-vsem-podvodnyjotel-v-dubai.

13. Устойчивое развитие предприятия, региона, общества: инновационные подходы к обеспечению : монография / под общ. ред. д-ра экон. наук, профессора О.В. Прокопенко. Польша : Drukarnia i Studio Graficzne Omnidium, 2014. 474 с. 


\section{References:}

1. Official web site of programme Green Key. Available at: http://www.greenkey.global/green-key-sites (accessed 29 January 2021).

2. Pijak Jana. 25 High Tech Hotel Innovations. Available at: https://www.trendhunter.com/slideshow/hotel-innovations/ (accessed 29 January 2021).

3. Tourism investing in energy and resource efficiency. United Nations Environment Programme . Available at: http://biodiv.unwto.org/en (accessed 29 January 2021).

4. Butik-gotel "Giraffe Manor": snidanok z zhy`rafamy [Giraffe Manor Boutique Hotel: Breakfast with giraffes]. Available at: http://www.travel.ru/wow/giraffe_manor.html (accessed 29 January 2021).

5. Gotel vseredyni sobaky "Dog Bark Park Inn", Kottonvud (shtat Ajdaxo), SShA [Hotel inside the dog "Dog Bark Park Inn", Cottonwood (Idaho), USA]. Available at: http://www.mirkrasiv.ru/articles/gostinica-vnutri-sobaki-dog-bark-park-inn-kotonvud-shtataidaho-ssha.html (accessed 29 January 2021).

6. Gribanova D. A. (2018) Ispolzovanie innovatsiy v deyatel'nosti gostinichnykh predpriyatiy [Using of innovations in the activities of hotel enterprises]. Modern innovation, vol. 3, no. 3, pp. 41-43.

7. Dukhovnaya L.L., Kholodtsova I. I. (2019) Innovatsionnye tekhnologii v gostinichnom biznese [Innovative technologies in the hotel business]. Service in Russia and abroad, no 7, pp. 58-73.

8. Kamushkov O.S., Tkach V.O., Yazina V.A. (2019) Innovaciyi svitovogo gotelnogo gospodarstva [Innovations of the world hotel industry]. Black Sea Economic Studies, vol 48, no. 2, pp. 52-55. Available at: http://nbuv.gov.ua/UJRN/bses 2019 48(2) 11 (accessed 27 January 2021).

9. Pecheritsa E.V. (2013) Zarubezhnyy opyt primeneniya ekologicheskikh innovatsiy v sredstvakh razmeshcheniya [Foreign experience in the application of environmental innovations in accommodation facilities]. National interests: priorities and security, vol. 34 , no. 223 , pp. $49-60$.

10. Pecheritsa E.V. (2013) Rossiyskiy opyt primeneniya ekologicheskikh innovatsiy v sredstvakh razmeshcheniya (na primere Severo-Zapadnogo federal'nogo okruga) [Russian experience in the application of ecological innovations in accommodation facilities (on the example of the North-Western Federal District)]. National interests: priorities and security, vol. 42, no. 231, pp. 38-45.

11. Pecheritsa E.V. (2016) Teoreticheskie i prakticheskie aspekty vnedreniya innovatsiy v turizme i gostinichnom biznese [Theoretical and practical aspects of innovation in tourism and hotel business]. Physical culture. Sport. Tourism. Motor recreation, vol. 1 , no. 2 , pp. $34-41$.

12. Roskosh vo vsem: podvodnyy otel $\mathrm{v}$ Dubai [Luxury in everything: an underwater hotel in Dubai]. Available at: https://planetofhotels.com/guide/ru/blog/roskosh-vo-vsem-podvodnyj-otel-v-dubai (accessed 29 January 2021).

13. Prokopenko O.V. (2014) Ustoychivoe razvitie predpriyatiya, regiona, obshchestva: innovatsionnye podkhody k obespecheniyu [Sustainable development of an enterprise, region, society: innovative approaches to ensuring]. Poland: «Drukarnia i Studio Graficzne Omnidium». (in Russian)

Kaplina Tatjana Poltava University of Economics and Trade

Krasnomovets Viktoriia Bohdan Khmelnytsky National University of Cherkasy

\section{INNOVATIONS IN THE DEVELOPMENT SYSTEM OF HOTEL ENTERPRISES}

One of the most important keys to the successful development of the hotel industry is the implementation of innovations in practice. In the current conditions, those companies that will be the first and best able to adapt to the new realities and rules of the game will gain a competitive advantage. The importance to introduce innovations in the practice of the hotel industry is substantiates in the article. Their essence is defined and the main functions are given. Among many types of innovations, the article considers ones of the most common: infrastructure and technological innovations. Infrastructural innovations involve a departure from the traditional format of the building or location of the institution. The scope of technological innovations is extremely wide and includes both the use of new information systems in marketing policy and the introduction of new technological tools designed to make the stay as comfortable as possible and attract the attention of the guest. Successful world examples of implementing infrastructural innovations in the hotel sphere are given. The essence of technological innovations is described, and variants of their application at hotel enterprises are given. The article pays special attention to the analysis of ecological innovations, which we consider as a subspecies of technological ones. The essence of ecological innovations is defined by which we understand new products, technologies, and also ways of the organization of manufacture and the social programs consisting of new or changed processes, methods, systems at which use in various areas and spheres of activity there are improvements of an environment. risks, pollution or other negative environmental consequences. Areas in which ecological innovations can be introduced into the practice of hotel enterprises are substantiated: waste disposal, room cleaning with ecological detergents, staff training, organic catering services, natural style interior design, purchase of ecological raw materials and others. Thanks to the introduction of environmental innovations in these areas, the hotel can significantly reduce the negative impact on human health and the environment. The systems of ecological certification of the hotel industry are analyzed and one of the most popular programs of voluntary international ecological certification of hotel business institutions - "Green key" is described. This program aims to reduce the impact on the environment, promote the implementation of sustainable hotel business management, as well as to raise environmental awareness. It is substantiated that there are obstacles on the way to the introduction of ecological innovations in the hotel business. They usually include the high cost of implementing environmental innovations or their development, the amount of resources (temporary and intellectual) that must be spent to learn to work with these innovative technologies. Today, competition rules are tightening, and today those who do not rely on eco-innovation risk losing very seriously in the future.

Key words: innovations, development, hotel enterprises, ecological innovations, «green» economy.

JEL classification: L8, Q55, Q56 